\title{
A SIGNPOST MEMORIAL TO WILLIAM SMITH
}

SIR,-A " scientific shrine" of the greatest interest to geologists is Rugbourne Farm, High Littleton, Somerset, where William Smith lodged from 1792-5 when surveying the local coal mines, for it was here that the fundamental principles of stratigraphy first became evident to him (cf. Cox and others, 1941, Proc. Geol. Assoc., 52, p. 21, pl. 2a). Visitors to High Littleton have had difficulty in locating this farm, and have found local residents woefully ignorant of the work of William Smith and of his connection with their village. It is, therefore, pleasing to record that, thanks to the initiative and persistence of Mr. J. B. Jones, of Swindon, and the action of the Clutton Rural District Council, a memorial signpost described by Mr. Jones as a substantial erection which does the local Council credit, has now been placed at the beginning of the bridle-path leading to Rugbourne. It reads : "To Rugbourne Farm/where William Smith, 'Father of/English Geology ; lodged, 1792-1795."

British Museum (Natural History),

L. R. Cox.

LONDON, S.W. 7.

16th October, 1951.

\section{SILICATE ANALYSIS}

SIR,-I much appreciate the thoroughness of the kindly review of the 2nd Edition of my "Silicate Analysis" in your September-October number, but in the concluding paragraph attention is drawn to a supposed error in the result of the silica determination in Appendix B, an error which is said also to have appeared in the 1st Edition. As, however, the reviewer himself has erred in this instance, a few words of explanation seem desirable.

The ignited residue remaining after the expulsion of silica by means of hydrofluoric acid consists of any $\mathrm{R}_{2} \mathrm{O}_{3}$ oxides contaminating the silica, plus the non-volatile residue invariably left by the hydrofluoric acid and which in the case of the ordinary " redistilled " grade is often considerable. The blank for the HF is accordingly added to the $\mathrm{SiO}_{2}$ figure and deducted from that of the $\mathrm{R}_{2} \mathrm{O}_{3}$ (the $\mathrm{R}_{2} \mathrm{O}_{3}$ being subsequently ignited and weighed on top of the residue in the same crucible). The correct figure for $\mathrm{SiO}_{2}$ therefore is 51.44 as given in Appendix B in both editions. In Appendix C, where the final results of the analysis are tabulated, a misprint causes the silica to appear as 51.47 and this may have contributed to the reviewer's misapprehension.

\section{Mineral Resources Division, \\ Colonial Grological Surveys, IMPERIAL INSTITUTE, LONDON, S.W. 7. \\ 16th October, 1951.} A. W. Groves.

(I stated in my review that the value for $\mathrm{SiO}_{2}$ given as 51.44 per cent presumably included the blank for HF. I still regard it as an error to place this value opposite a determination which gives $51 \cdot 14$ per cent. The final value for $\mathrm{SiO}_{2}$ should appear lower on the page, after the value of the blank for $\mathrm{HF}$ has been given, and not before.-S. R. N.)

\section{OLD RED SANDSTONE OF PORTSALON}

SiR,-Mr. Bishopp's note on p. 371 of the current volume suggests a Torridonian age for the red sandstone with conglomerates south of Portsalon.

The sandstones of this outcrop are tilted to the north in a "faulted" attitude, but it is believed that the fault is either completely older than the deposit or that only a slight amount of movement has followed the deposition of the red sandstones. If the northern edge of the outcrop of the Knockalla quartzites is examined carefully it can be seen, on many small, steeply inclined

VOL. LXXXVIL-NO. 6 
exposures away from the shore, that sedimentary infiltration and a reddish stain have run along joint cavities in the quartzite. The sediment infiltration suggests deposition against a scarp, possibly a fault scarp, though no fault has been demonstrated. It is considered that most, if not all, of the dip of the conglomerates near the present shore is original.

The observation of the sediment infiltration was checked by Sir E. B. Bailey and he unhesitatingly accepted the sedimentary contact of the sandstone series against a cliff of the metamorphic quartzite formation.

The above supports the Geological Survey's date, which was based on the very " Old Red" look of the sediments.

\section{Grological Survey of Anglo-Egyptian Sudan, KHARTOUM. \\ 6th November, 1951.}

Gerald ANDREW.

\section{DOUBT AND CERTAINTY IN SCIENCE}

SIR,-Two leaders of palaeontological thought in Europe have this year published discussions of the problem of extinction of faunas. (Both works were reviewed in this Magazine, 1951, vol. lxxxviii, pp. 303 and 372). The two following extracts summarizing their conclusions make an interesting comparison and provide food for thought.

"These wholesale disappearances and the sweeping changes in the population of sea and land which result from them always correspond with important geological events. Regularly they accompany great transgressions or regressions of the sea, tectonic upheavals, or climatic changes ; in short, they coincide with the great geodynamic crises which periodically modified the face of the earth."-C. Arambourg, 1951, in Paléontologie et Transformisme, p. 97.

"The supposition that flourishing groups of cosmopolitan organisms could be annihilated by mountain-building or changes in the distribution of land and sea is untenable and must emphatically be rejected .... It is therefore very short-sighted when, over and over again, organic evolution and above all extinction of faunas and fioras is represented as closely dependent on geological events."-O. H. Schindewolf, 1951, Grundlagen und Methoden der paläontologischen Chronologie, pp. 119, 121.

Both pronouncements are supported by an impressive array of facts.

The Sedgwick Museum, W. J. ARKELL.

CAMBridge.

19 th November, 1951.

\section{REVIEWS}

Proceedings of the Fourth Empire Mining and Metallurgical Congress, 1949. Edited by F. Higham. 1,139 pp. Published in two Parts at the offices of the Congress, London, 1950 . Price 40 s., or separately at $20 s$. each Part.

Some forty papers covering a wide range of topics were introduced during the course of the seven technical sessions comprising the main proceedings of the Fourth Empire Mining and Metallurgical Congress held in Great Britain in 1949. In detail, the sessions were concerned with (i) Empire mineral resources, (ii) modern prospecting methods, (iii) the effect of heat and humidity on workers in deep mines and metallurgical industries, (iv) drilling for petroleum, (v) the characteristics and resources of Empire coals and coal mining practice in Great Britain, (vi) mineral dressing, and (vii) mining and metallurgical industries. 